\title{
Marketing The Non-Profit Organizations,"The Jordan Museum as a case study"
}

\author{
May MuneerMjuli Ali*， Bashar M. Al Najdawi, Qusay Q. Khaleefah \\ Khaldoun N. Kanaan, Ihab Ahmad AwadAlomari, Ahmad Khaleel Musallam Abu Haniyi \\ Department of Hotel \& Tourism Science, Al-Balqa Applied University, Jordan
}

\begin{abstract}
The aim of this paper is to analyse the existing concepts of marketing and the difficulties of applying general marketing techniques in the Jordan Museum and highlighting the strengths, weakness, threats and opportunities that are facing the museum. The paper offers marketing suggestions that may influence and assist the Jordan museum to enhance its marketing structure. The gained information for the research was obtained byusing articles, books, case studies, interviews. This method is used to gain Varity of information, points of views, and attitudes. The questions deducted in the interviews focused on whether if the Museum in question is placed on the well-known tourist trail. Another focus was upon the tools \& techniques should be used in marketing. The paper also investigated if there is any marketing plan considered and whether the museums in Jordan has been discussed or even mentioned in any of the international tourism or cultural conference's Which Jordan is invited to. The result showed that The Jordan Museum lacks any marketing innovation and having no clear marketing plan. The museum can overcome this by reconsidering its priorities enclosing new marketing techniques.
\end{abstract}

Key Words: Museums, Marketing mix, Nonprofit Organization

DOI: $10.7176 / \mathrm{JTHS} / 40-08$

\section{Introduction:}

The Chartered Institute of Marketing defines marketing as:"Themanagement process responsible for identifying, anticipating, and satisfying customer requirements profitably". Marketing exists whenever there is a market, creating an exchange process to satisfy human needs and wants. Thus marketing is about a human activity directed at satisfying needs and wants through the exchange processes.

The exchange processes start with sellers searching for buyers, identify their needs, design attractive products, promote them, deliver them, and set prices.Normally people think that sellers are the ones who practice in marketing and control the whole process while actually this is not the only truth; buyers also carry on marketing activities. By searching for the products that satisfy their needs at prices that they can afford, customers also participate in marketing. It also necessary two recognize that there are two kinds of markets regarding to those who are in power.A sellers' market and a buyers' market. In the first one Sellershave more power. While in the buyer's market, buyers have the control.

\section{Marketing management:}

Kotler(1979) definedmarketingmanagementasTheanalysis, planning, implementation, and control of programs designed to create, build, and maintain beneficial exchanges with target buyers for achieving organizational objectives. Moving forward to identify the marketing Managers, most likely People's perception of them is about people who search for a sufficient number of consumers to purchase a company's product.

As mentionedearlier about people perception of sellers, the idea here is just the same.The marketing manager is responsible to restrict the time andcomposition of demand for the company's products and services. Customer's Demand (no demand, adequate demand, irregular demand, or too much demand) continuously change and may vary and thereforethe manager have to adapt to this change. Understanding and fluffing a demand is not an easy task.(Kotler, 1979).

There are a lot of questions should be raisedin order to evaluate the marketing acceptance in non-profit organizations, the most vital one is to find outwhether. The managers are familiar, interestedand aware of the importance of the use of marketing or not. The results shows that marketing is not managed carefully by the nonprofit organization in question (The Jordan Museum), comparing the management process of other departments such as accounting andfinance. 


\section{A Major differences between none and for- profit products marketing}

It easier to measure the product success through the amount of selling and its revenues gained rather than considering customer satisfaction and repeated visits for instance, which means that non-profit products is completely deferent from marketing profitable ones

In marketing we usually market something tangible,so in the hospitality sector we are trying to tangible the intangible products through some actions. Forinstance, in a hotel restaurant, a staff may tide the tissue for you putting it in your table; half of the tissue will look likean arrow aimed toyoutelling you that we made this for you. Here we tangibalize a hospitality seen. ( Heaton, 2015 ).

Moving to another point, transaction as a mean of marketing concept is an exchanging process, it is about A gives $\mathrm{X}$ to $\mathrm{B}$ and gets $\mathrm{Y}$ in return "In Museums we do not have a tangible $\mathrm{X}$ to give, nor a tangible $\mathrm{Y}$ to gain. So how this Transaction happens in such unprofitable organizations?

Museums actually do have $\mathrm{X}$ to give but not a usual one, not a common one, not a tangible product to be consumed by the customer. Our $\mathrm{X}$ here is the experience that burned deep in the visitor's memory,an unforgettable memories. On the other hand The $\mathrm{Y}$ which the museum gains in return is the visitor satisfaction, the educational purpose being accomplished."For marketing a museum, it's all about marketing( Lovelock ; Patterson,2015).

\section{The marketing mix}

There is a set of component that shape the process starting from the designing stage until the selling point and that what is the marketing orientation is about. These components as Kotler(2008) have discussed,based on Jerome McCharty's “4Ps are: Product, Price, Promotion and Place. Thoseelements explain that everything in the production process from $\mathrm{A}$ to $\mathrm{Z}$ is marketing. Now let us explain each component separately to gain clearer image about marketing orientation regarding to non-profit institutions like museums:

\section{Product:}

Product is anything that can be offered to a market for attention, acquisition, use, or consumption that might satisfy a want or needincludes physical objects, services, persons, places, organizations, and ideas. Now what if no one needs or wants the product! Then simply we do not need to go ahead in the process because it will be useless. No effort will change the selling amount. For museums what is theirproduct?The visitor may view the museum product as the galleries, the special exhibitions and the other parts of the museum open to the public or all of theprevious adding to it the research facilities, the service areas and places to meet friends and relativesandcolleagues, such as a museum restaurant or café. ( McLean 2012)

It is vital for all of the areas mentioned to meet the needs of a visitor and to achieve his/her satisfaction .The attractiveness of a museum have to be there otherwise it will not achieve its recognition and popularity regardless to the amount of money we are spending on the marketing plans and tools. It is something affective and useful if the museum takes into accounts the potential visitors opinions about how would they like to see the objects, gain new ideas of how we could represent our collections in the best way that reflects their essence and deliver their message (Kotler, 2008).

\section{Price:}

It is the amount of money charged for a good or service. More broadly, price is the sum of the values consumers exchange for the benefits of having or using the product or service. The only price that a visitor pays for this non-profit institution is the entrance fee; amount of money paid to enter a place or a facility;according to this how we can make this feeeffective?

The ICOM (International Council of Museums) in their practical book " running a Museum" telling us that If a museum really want to make a profit through that fee it should not be the same for every visitor: If museums wants to make healthy profits, it can simply achieve that byofferingthe tour operators discounts. Free tickets for some important contacts will definitely please Sponsors and donors.One of The ICOM potential solutions is toincrease the profit through thecooperation with other museums to launch a common ticket valid for different museums. Gigantic museum could also offer a free entrance and that to encourage people who do not likely visit museums or they cannot afford the fee. 


\section{Promotion:}

When we talk about promotion, we are talking about advertising, sales, public relation and many other things that could accomplish our marketing goals. Those activities may vary depending on the museum location and the popularity scheme. A museum joining spectacular objects will gain visitors easily, and accordingly the ICOM suggested that such a museum does not have to pay a great deal of money on promotion since it is already in the top, unlike the small museums with modest collections which have to work harder in promoting their museum . The researchers of this paper may not go with this assumption completely because there is a point where a good museum has to spare no effort to secure its high position because in that level the competitiveness will range from being excellent to being intensive. (Baker;Saren,2016)

\section{Place (the distribution channel):}

It is a set of independent organizations involved in the process of creating a product or service available to the consumer or business. The distribution of a product is important but not for a product that is not ready to be in market otherwise the customer will feel disappointed(Segetlija, 2004).

But regarding a museum,aren't they fixed in a specific location? When dealing with museums, the Place element is represented by Visitor's transporting to and from the museum. The museum's location must be easy to reach (accessible), if not it must at least provide the visitor a safe and a direct access to themuseum by offering them transporting service. The Marketing mix must be applied in the museum long term strategy that includes its marketing plan and activities. The strategic plan has to be constantly updated so can surmount any sudden changes or difficulties. (Fan et. al., 2015)

Customer orientation:Gaining a satisfied customer and having a clear brand is the main aim for any business which will eventually lead to generate profits. As a non-profit organization, we have to put the customer first and reward employees for serving our customer well exceeding their expectation. (Baker; Hart, 2008).

\section{Personal characteristics affecting consumer behavior:}

\section{Cultural factors}

- Culture is the main element determining a person's needs and behavior. It creates the basic thoughts, perceptions, wants, and attitudes that a person learns day after day living in his/her society.

- Subculture: By this, we mean groups of people with shared value system based on common experiences and situations.

- Social classes. These are relatively permanent and ordered divisions in a society whose members share similar values, interests, and behaviors (Sargeant; MACQUILLIN,2016).

\section{Social factors}

These factors presented by the situations and behaviors that motivated by a specific interaction with reference groups. Also family affects a

consumer behaviors and wants. Peoplearound the person could simply force someone to act regarding to their existing around.

\section{Personal factors:}

Age is one of these factors, the needs and wants of a consumer change while he or she is getting older. The economic status also affects the amount of money that a person will spend on such a non- basic needs such as affording to visit a museum. Self-image is another important factor that may affect the process.

\section{Psychological factors:}

It is obvious that the psychological characteristics determine how the person deals with things in the surrounding environment. The psychological factors represented in the four well-known segments: motivation, perception, learning and beliefs which all together affect the purchasing (Kotler, 1997):

1. Motivation: Thething changes a want into a need creating a respond toward this need and motive.

2. Perception: choosing a specific product and kinds of information to create a meaningful picture of the world.

3. Learning: learning through experiences and events that may change a person's attitudes. 
4. Beliefs and attitudes: A belief: is an existing perception about something. An attitudeis the final stage just after the belief. It reflexes someone feelings and evaluation toward an object.

\section{Methodology:}

This study investigates the marketing status in the Jordan Museum. A qualitative methodology was used to gain information and its analysis. A group of questions which focused on the marketing techniques used to promote the museum and the barriers facing the museum was the source of data gained. However other parties' intervention was questioned too due to the important role they may play regarding this matter such as the Jordan Tourism Board and the Royal Jordanian Airline.

According to Bruce and Berg (2001), there are three various qualitative interview kinds: the closed/structured, semi structured and open/unstructured. The Open interviews method was selected due to for the purposes subjected in this paper and nature of data needed to be collected. An open interview presents questions that are prepared in advance covering the topic that a researcher may want to study. The researcher conducted twenty two open interviews with participants whom seven from the Jordan Museum, two from the Jordan tourism board, thirteen form different tour guide agencies.

This type of interview depend on the researcher building an solid general ground in advance for the interview by preparing open questions provide by this more flexibility for both the interviewer and the participant . This technique enhances the result of the interview by giving the participant their freedom to reflect his point of view and perspectives and beliefs leading to more reliable trusted answers.

The Sum of 22 respondents including 7 from the Jordan Museum , 2 from the Jordan Tourism Board , 13 from different tour guide agencies.

\section{Results \& Discussion}

\section{Marketing in the non-profit world:}

There are number of great scholars whom havechange our marketing perspective such as Kotler, Levy, Shapiro and Zaltman.Those researchers reshapethe concept in our mindsregarding the Non-profit organization's marketing, now we no longer see marketing as a tool to gain profits rather than we consider it as an integrated part of the institution's master plan and strategy. Their contribution in marketing techniques enhance our understanding as managers and assets our plans and strategies. (Dolnicar, Lazarevsk, 2009).

Marketing barley had an attention in the nonprofit institutions. There are many reasons behind such phenomenon for instance:

1.The matter of neglecting: The Owners of the nonprofit organization often do not recognize or realize the vital role of marketing in their organization. Eventuallyleading to raise wrong assumptions such as "the good work will sell itself" which is not an absolute truth.

\section{Financial issues}

When the organization is losing its funding managers may assume that the best solution is to cut the public relation. Still, there is few of owners understand their lack of experience in this field.

According to David Williamson (2009)" Marketing \& Communications in Nonprofit Organizations " scientist don't think twice about overruling marketing professionals on audiences, messages, tactics — the very essence of marketing strategy".

The marketing department in a museum may occurs under variety of different names such as Communications, Advancement, External Affairs, Public Relations, or Brand Management but the main functionare quite the same "to define and then defend an organization's position, and move it closer to success in its mission.

\section{The 5ws}

As Williamson (2009) illustrates the main pillars to guarantee the success of an organization so this paper present similar formula for specific questions that any nonprofit organizationshould be aware of The Five Whats. 


\section{What \\ special ? \\ What \\ audience?}

Journal of Tourism, Hospitality and Sports

ISSN (Paper) 2312-5187 ISSN (Online) 2312-517\% Unternational Peer-reviewed Je

Vol.40, 2019

The Five

DOI: $10.7176 / \mathrm{JTHS}$

Whats

subject?

(1)What type? : means the type of the organization. Is it public? Privet? Is it forprofit? Nonprofit?

(2)What do you do? : is acquiring about your goal. What is your job? What do you want to do? Why your organizationexists?

(3)What audience? : Are you addressing? For whom you are creating your product? What kind of people you will be serving?

(4)What subject? What need are you fulfilling? What problem are you solving through your product? What are you delivering? In which field you are?

(5)What special? It is about the uniqueness about your institution. What do you got and the others don't? What is that thing that will make me favor you above the others? What put you right there ahead of everyone else?

Marketing Barriers: The following points present the most serious problems that affect the Marketing process.

1. The diverse taste of cultural and needs.

2.Financial and human recourses.

3. The Unwillingness of Managers, staff and fundraisers to change or to experience something new

4. Almost all nonprofit-organization mangers Set a short-term goals and that not very helpful though they are necessary too.

5. The fast developing of technology and inability to adopt it, therefore following traditional marketing techniques.

6. The managerial process and the marketing process being inapplicable and incoherent.

7. Inaccurate information due to the lack of marketing professionals (Baker 2016).

\section{The strategy}

(1)For whom?

The strategy of marketing a museum is lay out for managers, financial supporters, staff whether they are paid or volunteers, the rest of the stakeholders and the potential parties in the tourism sector .

\section{(2)What's its aim?}

The strategy main aim is to enhance the ability of all these parties to collaborate and augment their organization positive perceptions in their consumer minds and widen the range of the museum brand scope(Wales, 2013).

\section{(3)What to achieve ....}

1. To increase the visitors' number of the Jordan museum.

2. Enhance the sufficiency of the museum performance.

3. Raise the awareness of the Heritage, social and culture.

4. Toimprove the ability of all the potential parties( stake-

5. Holders) to collaborate to augment their organization positive perceptions in their consumer minds and widen the ring of the museum brand scope.

6. Promoting the uniqueness of The Jordan museum. (Duque-Zuluaga ;Schneider, 2008).

This may be fulfilled through:

1. Responding to the customer needs eventually achieving their satisfaction.

2. Designing a captivated brand that may attract those who are a cultural admirer smoothly.

3. Demonstrating the benefits that a volunteer may gain by working in The Jordan Museum.

4. Strengthen the community engagement

5. Bring the directly inside new markets by working with the Tourism Ministry.

6. Develop the staff's marketing skills

7. Promoting a significanceexperience that The Jordan museum collections offered.

8. Using the available resources sufficiently since it is difficult to secure a sustainable marketing resources )

9. Overcoming the obstacles that hold back the local community from visiting a museum

10. strengthen and reshaping the messages that are being deliver to the museum audience by which we are telling our museum story and our educational aims. (Gonzalez et. al., 2002). 


\section{(4)What kind of experience does your museum offer to visitors?}

Answering this question is the Golden Key to lay out the most suitable and effective strategy. It is not only a description of the activities whicha visitor can enjoy at the building. (Arnold; Tapp, 2003)

\section{The Marketing Plan}

A marketing plan is built dependingon four basicelements:

1. Situation Analysis andDetermining Market Opportunity.

2. Setting Marketing Objectives.

3. Strategy and Program Development.

4. Implementation, Monitoring, Evaluation.

\subsection{Situation Analysis and market opportunities}

It is about analyzing your spot, where are you standing, what are your Opportunities, Threats, your museum Strength and Weakness points .In order to fulfill this it is vital to sort out a " SWOT analysis ", doing this will widen your horizon and shall shed light upon your best shoots.

According toMork the Head of Communications and Marketing, NorskFolkemuseum, Oslo both the museum Strengths and Weaknesses are consider to be measured inside the museum according to specific Internal factors while we study Opportunities and Threats by examining an external factors outside the museum.

\section{Internal factors:}

Each internal factor will represent a weakness / strength to the institution. These factors emerge in the museum's location, its building status, budget, collection's quality, staff quality Every museum will have strengths and weaknesses, so it is not whether the museum has weaknesses or not, it is rather overcoming and seeing them as strengths. Sometimes political and economic struggling in a country enables its museums to get advantage of this weakness using the situation to promote themselves.

\section{External factors:}

These factors are represented by the outdoor, outside the museum walls such as the governmental regulations and legislation, other heritage sites, recreational tourism spot and other hospitality facilities (McDonald; Wilson 2016 )

Other external factors:

1. The politicalsituation

2. The demographicshifts

3. economic cycles

The customers themselves (why do they come to the museum, when they do take the decision to come? consider their age, gender, work-field income and their educational level.

Allthese factors could represent threats or opportunities for the museum, so they should be analyzed carefully and try to overcome them as possible as the manager could.

\section{Setting Marketing Objectives (Goals):}

A goal is a "statement of being" for a plan. While the completion of a goal signifies the end of your plan, the objectives, strategies, and tactics are the means to that end" (Good, 2007).

The most important goal is to determine the deadline for fulfilling the museum's objectives and to set out a master schedule for weekly, monthly and an annual activity. Each museum hasdiverse objectives but there is one single goal that all product providers share and it is the most important, this objective lays in determining howto reach your target audience. Any mistake in setting the objectives may lead to a disaster. There must be a cooperation between all the museum's departments so no objective may contradict with another objective. The aims clarify the seen providing the museum with the besttechniques to accomplish the mission (Chhabra, 2009). 


\section{Strategy and Program Development :}

Here and after the marketing position is being established, it is time to address the essential elements of the marketing mix we mentioned previously: Product, Price, Promotion and Place.

Is a single strategy enough to monitor the whole situation? Or we should have multi strategies to guarantee reaching our goals?

For the researchers of this paper, it is enough to have one to fulfill the job as long as it is comprehensive and effective. It is also sometimes difficult to balance between the sum of strategies we got for the museum and that could simply mislead us and randomly take us to a thorny bath rather than a lighted smooth one. Now the museum should think how to present the institution to the public and therefore developing the needed processes.

\section{Developing marketing budget:}

The strategy also includes the developing budget. The budget should cover the staff salaries, events and activities expenses, advertising, promotions preparing, regular publication, brochures, participation in trade shows and the expenses of market research.

\section{Implementation, Monitoring, Evaluation}

The marketing plan should applied to all parties starting with the Junior staff paid or volunteer moving to the senior staff ending with the customers." Now place all the museum objectives in the marketing plan to gain the best performance. After that, a museum shall go through market tests before fully applying the strategy (McDonald;Wilson, 2016).

\section{Evaluation:}

It is one of the vital tools used to decide the effectiveness of themuseum plans and strategies. It is simply the success measurement. Evaluation is the final stage in the planning process. In order to set the best aims and achieving them the museums need to start evaluating those aims. (Bryson, 2018).

Gary Edson (2013) the Executive Director of Museum of Texas Tech University at Lubbock illustratesan example for this evaluation by setting an institutional self-evaluation by which will help the museum's staff to :

- Identify needs in society

- Define its relation to the mission of the museum

- Evaluate its capabilities as a museum

- Assess its external environment

- Set objectives for the museum

- Select strategies for the museum

- Design curatorial, exhibition, educational and other public programs for the museum

- Determine a future budget for the museum

- Evaluate the overall performance of the museum. 
Table (1): The Jordan Museum SWOT Analysis

Strengths \& Weaknesses are determined by the internal factors we mentioned before in this research. We will examine some of these factors and apply them in the SWOT analysis:

\begin{tabular}{ccc}
\hline The factor & $\begin{array}{c}\text { Strength(s) } \\
\text { Weaknesses(w) }\end{array}$ & Description \\
\hline Budget & W & A shortage in money resources \\
Location & $\mathrm{S}$ & Easy access \\
Collection & $\mathrm{S}$ & $\begin{array}{c}\text { Unique collections } \\
\text { Onecialized departments }\end{array}$ \\
Building status & $\mathrm{W}$ & $\begin{array}{c}\text { Onlysing a marketing } \\
\text { Department }\end{array}$ \\
Staff quality & $\mathrm{S}$ & $\begin{array}{c}\text { New buildings with a modern } \\
\text { design }\end{array}$ \\
\hline
\end{tabular}

Another extra strength presented by parking space, no entry fees, strong history routes.Regardingweaknesses, the Jordan museum has to focus on having a marketing department so there will be more advertising.

Table (2):The Jordan Museum's Opportunities \& Threats

\begin{tabular}{|c|c|c|}
\hline The factor & $\begin{array}{c}\text { Opportunities (O) } \\
\text { Threats (Th) }\end{array}$ & Description \\
\hline Political situation & $\mathrm{O} / \mathrm{Th}$ & $\begin{array}{l}\text { Arab Spring } \\
\text { Depending on how the museum } \\
\text { cope with the situation }\end{array}$ \\
\hline Governmental regulations & $\mathrm{O}$ & Smooth \\
\hline $\begin{array}{c}\text { Nearby recreational facilities } \\
\text { or heritage sites }\end{array}$ & $\mathrm{O}$ & $\begin{array}{c}\text { there is no other museum in the } \\
\text { area nor any other nearby } \\
\text { tourism sites }\end{array}$ \\
\hline Local community awareness & $\mathrm{Th}$ & $\begin{array}{l}\text { Huge slice of locals unaware of } \\
\text { the importance of this museum }\end{array}$ \\
\hline
\end{tabular}




\section{The potential role of other parties which must be engaged in the marketing:}

\section{The role of Ministry of Foreign Affairs}

The role of Ministry of Foreign Affairs is represented in supporting the museum through the coordination between the formal concerned parties to hold an International cultural, heritage workshops for the purpose of the Jordanian heritage acquainting and through holding a specialized seminars and lectures about the Jordanian heritage .

They also can distribute Tourism publications including all the museums in Jordan with " The Jordan Museum " on top. They may present documentary films about the Jordanian culture and its people's life style. The role of Ministry of Foreign Affairs it is complementary to the Tourism Ministry and the Royal Jordanian role. Each party alone can accomplish nothing impressive and efficient.

\section{The role of The Ministry of Tourism and Antiquities}

1. Qualifying the trained staff to match the notable increasing in the laborer in Tourism sector in Jordan in cooperation with the tourism departments in the Jordanian universities to be aware of the value of museum in the tourism world.

2. Increase the awareness of the local community in Jordan about the importance of the museum in the Jordanians' life.

3. Distribute publications and designing advertisements targeting the local community especially and the foreign tourist generally.

4. Designing educational programs for schools and universities to introduce the students to the museum, prompting them to recognize the heritage and cultural treasure that they have and educate them about the way that theyshould treat the tourist and how to deal with them considering the WOM (tourists talking about their gained perspective about a specific service or place they had visited) an indirect marketing tool.

5. Engaging the antiquities students in the maintenance and restoration processes for the museum current objects, so we could enhance their responsible feeling toward their heritage.

\section{The Royal Jordanian role.}

The biggest portion of responsibilities is hold out by the Royal Jordanian, since it is the air carrier with the Golden Prize that had been awarded by the Spanish tourism club in 1995, as the best airline company in the world.It has to promote the Jordanian museums abroad. It can fulfill that through its various paths and net all over the world. It can give free tickets for those who can contribute in enhancing the Jordan museum image or by affording their expertise. So the royal can play an important role as an indirect -mediator.

\section{Recommendation:}

It is vital to collaborate with the intermediates to install the Jordan Museum on the Jordanian Tourism packages is important to develop the current situation of the Museum in question. The museum should also increase its participation in International Exhibits. Establishing a "Friends of the museum" association will help too. Publishing a Management Museum Guide book specific for the Jordanian museums where this Guidebook is more realistic and applicable is a must. Working with the Jordanian TV to find the appropriate program to insert an episode about the Jordan Museum and Establishing a Museum T.V channel will be very fruitful and effective too.

Using various Marketing tools is very important, there are multi choices that a museum could take as a marketing tools and they set two kinds of marketing: Using the Internet (Online) and Offline. Online will be Through launching an online educational programs on the museum's website, Interact with customer using the social media (Facebook, twitter....etc) (Strauss ; Frost. 2016).

Using Google Adwords to advertise after evaluating the marketing budget. Strengthen the relation with customers through placements on websites and blogs. The museum can also setting up pages for a special events and activities. Communicate with potential donors using an outreach email. The Offline will be represented in printing brochures and annual reports, also through public relations placements like radio, TV, magazines and newspapers.A lot of actions may be useful to strengthen and enhance the Museum image in customers minds, in table 3 below there are some actions that are need to be taken by the Museum board (Lehman ,2008). 
Journal of Tourism, Hospitality and Sports

Table (3): Actions needed to be taken by the Jordan Museum Board

\begin{tabular}{|c|c|c|c|c|c|c|}
\hline $\begin{array}{c}\text { Target } \\
\text { Audience }\end{array}$ & $\begin{array}{c}\text { Local } \\
\text { community } \\
\text { (adult ) }\end{array}$ & Universities' students & $\begin{array}{l}\text { Schools' } \\
\text { students }\end{array}$ & $\begin{array}{l}\text { Abroad visitors } \\
\text { (outcome visitor }\end{array}$ & Volunteers & Donors \\
\hline The Action & $\begin{array}{l}\text { Education } \\
\text { seminars }\end{array}$ & $\begin{array}{l}\text { Provide a lab for the } \\
\text { archaeology's students } \\
\text { Educational programs }\end{array}$ & Workshops & $\begin{array}{l}\text { Participate in the } \\
\text { museum activities }\end{array}$ & $\begin{array}{c}\text { Advantages and } \\
\text { a nameplate } \\
\text { on the museum } \\
\text { hall's wall }\end{array}$ & $\begin{array}{l}\text { Invite them to } \\
\text { all the activates } \\
\text { held }\end{array}$ \\
\hline
\end{tabular}

In conclusion, museums should never lose the faith in their potential to fulfill their goals through their special collections and an effective management strategy combined with the best marketing plan. For The Jordan museum the opportunities are enormous and the only main weakness that the museum is suffering from is the limited budget and not having a marketing strategy or even a marketing department or office,but with the marketing suggestions we offer in this paper the museum can easily overcame those obstacles.

\section{References:}

Arnold, M. J., \& Tapp, S. R. (2003). Direct marketing in non-profit services: investigating the case of the arts industry. Journal of services Marketing, 17(2), 141-160.

Baker, M. J. (2016). What is marketing?. In The Marketing Book(pp. 25-42). Routledge.

Baker, M., \& Hart, S. (2008). The marketing book. Routledge.

Baker, M. J., \& Saren, M. (Eds.). (2016). Marketing theory: a student text. Sage.

Boylan, P. J. (Ed.). (2004). Running a museum: a practical handbook. International Council of Museums, ICOM.

Bryson, J. M. (2018). Strategic planning for public and nonprofit organizations: A guide to strengthening and sustaining organizational achievement. John Wiley \& Sons.

Chhabra, D. (2009). Proposing a sustainable marketing framework for heritage tourism. Journal of Sustainable Tourism, 17(3), 303-320.

Dolnicar, S., \& Lazarevski, K. (2009). Marketing in non-profit organizations: an international perspective. International marketing review, 26(3), 275-291.

Duque-Zuluaga, L. C., \& Schneider, U. (2008). Market orientation and organizational performance in the nonprofit context: Exploring both concepts and the relationship between them. Journal of Nonprofit \& Public Sector Marketing, 19(2), 25-47..

Edson, G., \& Dean, D. (2013). Handbook for museums. Routledge

Fan, S., Lau, R. Y., \& Zhao, J. L. (2015). Demystifying big data analytics for business intelligence through the lens of marketing mix. Big Data Research, 2(1), 28-32.

Gonzalez, L. I. A., Vijande, M. L. S., \& Casielles, R. V. (2002). The market orientation concept in the private nonprofit organisation domain. International Journal of Nonprofit and Voluntary Sector Marketing, 7(1), 55-67.

Heaton, J. (2015). Museum marketing for non-marketers. Obtenido de: http://www. tronviggroup. com/museummarketing.

Kotler, N. G., Kotler, P., Kotler, W. I., \& Kotler, N. G. (2008). Museum marketing and strategy

Kotler, Philip (1979), "Strategies for Introducing Marketing into Nonprofit Organizations," Journal of Marketing. 43 (January). 
Lehman, K. F. (2008). Museums and marketing in an electronic age (Doctoral dissertation, University of Tasmania).

Lovelock, C., \& Patterson, P. (2015). Services marketing. Pearson Australia.

McLean, F. (2012). Marketing the museum. Routledge

McDonald, M., \& Wilson, H. (2016). Marketing Plans: How to prepare them, how to profit from them. John Wiley \& Sons.

Sargeant, A., \& MACQUILLIN, I. (2016). Marketing for nonprofit organisations. In The Marketing Book (pp. 555-576). Routledge

Segetlija, Z., Mesarić, J., \& Dujak, D. (2011). Importance of Distribution Channels-Marketing Channels-for National Economy. In 22nd CROMAR Congress.

Strauss, J., \& Frost, R. D. (2016). E-marketing: Instructor's Review Copy. Routledge.

Williamson, D. (2009). Marketing \& Communications in Nonprofit Organizations. Center for Public and Nonprofit Leadership, Georgetown University. 